\title{
Child Language Disorder in ADHD Type
}

\author{
Putri Hotma Aryanti Siregar ${ }^{1(*)}$, Agustina $^{2}$
}

\author{
${ }^{1}$ Universitas Negeri Padang, Indonesia, \\ ${ }^{2}$ Dep. of Indonesia Language Education, Faculty Language and Art, Universitas Negeri Padang, Indonesia \\ *Corresponding author.Email: putrisiregar295@gmail.com,agustina@fbs.unp.ac.id
}

\begin{abstract}
The purpose of this study is to explain children who experience language disorders in the type of ADHD (Attention Deficit Hyperactivity Disorder). This research is a qualitative study by examining the disorder that occurs in a child named Bima who has ADHD, which is a language customer or S-LI (Speech or Language Impairment). This research shows that there are two problems experienced by Bima in language disorders, namely (1) phonological problems and (2) pragmatic problems. Bima has a language disorder because he has ADHD (Attention Deficit Hyperactivity Disorder). However, handling this language disorder can be done by frequently communicating with children, developing speech, and giving peer tutors and reading on an ongoing basis. Because language is important to be able to communicate and socialize, especially in children so that they can follow the learning process carried out in the school environment.
\end{abstract}

\section{Keywords: ADHD, language disorders, phonology, pragmatic, penanganan}

\section{INTRODUCTION}

Speaking is the same as breathing naturally for humans at all times. However, if that is not done then our identity as humans will no longer appear. Because the thing that most distinguishes us from other creatures is language (Indah: 2017).

Khoiriyah (2016) argues that language development in children is a benchmark that the child has normal language development so that in social life children can interact well. To learn what is around the child's environment, language is the most important foundation. Language skills are closely related to the cognitive development of each child. The most frequent development found in children's cognitive development lies in language and speech disorders (Sunanik in Nadwa, 2013). Specifically cognitive impairments can cause cognitive decline in language development and communication skills in children (Louise in Indah, 2017).

Language disorders such as SLI are often experienced by children with ADHD type (Attention Deficit Hyperactivity Disorder) forms that are always the same that is due to lack of attention and excessive activity. ADHD disorders can be identified when a child is not yet 7 years old and can occur in the school environment, home, playground or other social environments (Iffa, 2014). In addition, ADHD can also cause problems in the development of language skills (Dita, 2014).

Elizabeth (1978) discusses in her book that the problem of children's language disorders in the type of ADHD, this study seeks to continue previous research using a child research subject named Bima with ADHD. Bima can be said to be problematic because language development is different from children at their age. Children are categorized too late to talk if the level of quality of the development of talking children with peers can be known through mastery in the accuracy of the use of vocabulary. Atchinson in A. Kholid and Andika Dutha Bachari (2009 p.50-56), the stage of children's abilities are presented in table 1.

Tabel 1. Children's Language Development Stage

\begin{tabular}{ll}
\hline Stage of Language Development Ages & Stage \\
\hline Crying & Born \\
\hline Snoring (produces vocal but not clear) & 6 weeks \\
\hline $\begin{array}{l}\text { Babble (produces vowels and } \\
\text { consonants) }\end{array}$ & 6 months \\
\hline Intonation pattern & 8 month \\
\hline Speech one word & 1 year \\
\hline Speech two words & 18 months \\
\hline Infection of words & 2 years \\
\hline Question and deny sentence & $21 / 4$ years \\
\hline Rare and complex construction & 5 years \\
\hline Old ripe utterances & 10 years \\
\hline
\end{tabular}

(Source: Atchinson in A. Kholid, 2009)

Based on the above table, a 10 -year-old boy named Bima should have mature language skills, especially in the case of old age or pragmatics. However, Bima was just the opposite, he experienced problems with speech utterance and often failed to provide answers to questions posed by his interlocutors. 


\section{METHOD}

This study uses descriptive qualitative methods because researchers provide qualitative descriptive data relating to the phenomena obtained in the field in the form of language disorders in children aged 10 years. This study provides an overview of the data from research results that have been found on certain subjects. The selected research subjects are subjects who experience language disorders due to disturbances in the center of attention and excessive activity.

The focus of this study is children aged 10 years who suffer from speech disorders. Data sources in this study are children who have difficulty communicating and with the characteristics of ADHD (Attention Deficit Hyperactivity Disorder, 10-year-old Milky male and attend school at MI Al-Ikhlas, Riau. The child is in class $2 \mathrm{MI}$ and from a family of social status middle up.

This type of research is a case study. Syamsuddin (2009) suggests that a case study is a detailed examination of a setting (a detailed examination of one setting) or one subject (one single subject) or a place for storing documents (one single deository of document) or one particular event (one particular event).

Related to case study research, Pujiati et al. (2018) said "There are 6 procedures that the research must carry out, namely (1) case identification, this stage is the beginning of the case study research. The researcher tries to identify or detect a case; (2) problem identification, at this stage the researcher determines the problem in the case; (3) diagnosis, at this stage the researcher begins to determine the form of the problem in the form of an abnormality or disability; (4) prognosis, at this stage the researcher tries to predict the effect that will be experienced by the child who has the case; (5) remedial, this stage is in the form of healing or improvement in children who have cases and (6) evaluation researchers conduct a final evaluation taking into account the results obtained from the 5 previous stages. "

The technique of collecting data is done by recording and interview techniques. A recording technique for recording the activities of a research subject and identifying language difficulties experienced by the subject. Interview research conducted by researchers by giving open questions to parents and teachers who teach in the subject's class.

\section{RESULT AND DISCUSSION}

\section{Case Identification}

Research subjects were identified as having language disorders since the age of 2 years and were declared to have ADHD (Attention Deficit Hyperactivity Disorder) disorders by a psychiatrist who handled a child named Bima. Cases experienced by research subjects can not be separated from the conditions of birth. Bima's mother did not know that she was pregnant with her youngest child because she always menstruated every month. When the womb was 5 months old, Bima's mother was treated and diagnosed with liver disease so she was given liver medicine. After 3 months of being hospitalized, the doctor advised us to get an ultrasound, then it was discovered that Bima's mother was pregnant and her womb was 5 months old. At the time of 6 months pregnant, the mother was walking in the market and accidentally fell on the road and the baby had drunk a lot of blood so the doctor had to do a cesarean section. At birth the baby weighs less than 500 grams, although born prematurely the physical condition and limbs are all normal. This incident can cause the baby to lack of oxygen due to complications at birth.

This is in line with the opinion of Van Tiel (2015) in his book entitled My Children Too Late to Speak. In the book, Van Tiel explains that the history of knowledge about children who have distraction and hyperactivity disorders already existed in 1902. At that time it was discovered that newborn children had infections or inflammation of the brain and lack of oxygen, it turns out at the age of 4-5 years many of them experience hyperactivity or excessive activity. In 1947, the symptoms were then given the name minimal brain damage by Strauss and Lechtinen. However, at that time it could not be ascertained because the technology was not as sophisticated as now. To prove the many differences that arise, the name of the symptom is changed to minimal brain dysfunction.

\section{Identification of Problems}

The problem experienced by a child named Bima is a language disorder due to ADHD (Attention Deficit Hyperactivity Disorder) which causes unable to concentrate, always daydreaming, lack of focus, always joking, so it is difficult to be invited to communication while learning in class. Not only that, children always use unclear vocabulary when communicating and also often do not connect when asked by the teacher.

Language disorders faced by children named Bima in communication can be categorized in phonological and pragmatic problems. The phonological problems faced by a child named Bima are problems when sounding the last letter of a spoken word by using phonemes at the end of a word, phoneme removal or phoneme replacement / k / being / $\mathrm{t} /$ in a word. Not only that, Bima often eliminates phonemes when communicating.

\section{Phonological Problems}

The following data shows language problems with phonological problems experienced by Bima when communicating. Following are the language mistakes conveyed by Bima by replacing the phoneme / $\mathrm{k} / \mathrm{being} / \mathrm{t}$.

\author{
Data 001 \\ Bima's Mother: "Siapa nama kakak Bima" \\ Bima : "tatak Bima itu Lia \\ Bima's Mother: "bagus".
}

Data 001 shows conversations conducted by Bima's mother who asked Bima what Bima's brother's name was. Then Bima said that Bima's sister's name was Lia. The phonological problem seen in the data above is that it changes the phoneme / $\mathrm{k} /$ to / $\mathrm{t} /$ so the sound that is heard is wrong. 
The following data shows the language errors submitted by Bima by adding the phoneme [n] to the last letter.

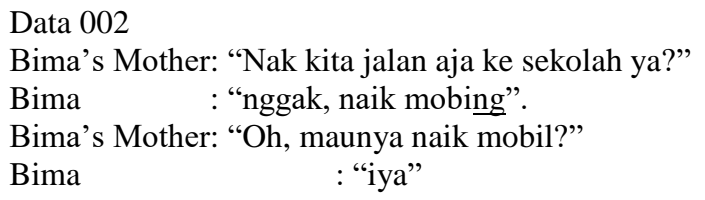

Data 002 shows a language disorder with phonological problems faced by Bima when he said the word car, he added the phoneme $[\mathrm{y}]$ to the last letter so that the sound that was heard was mobing.

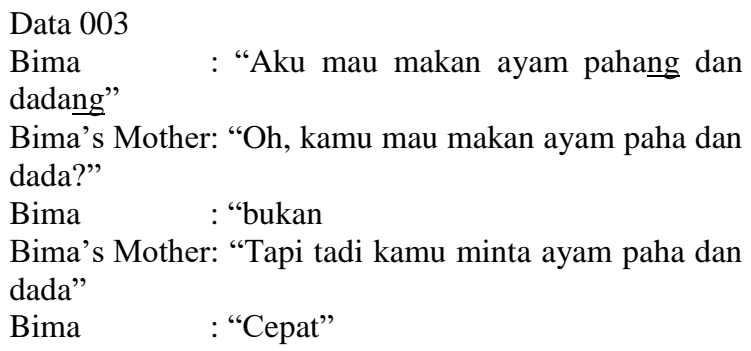

Data 003 shows a language disorder with phonological problems faced by Bima when he said the word instead he added the phoneme [ $\mathrm{y}$ ] to the last letter so that the sound of the sound that was heard was bad.

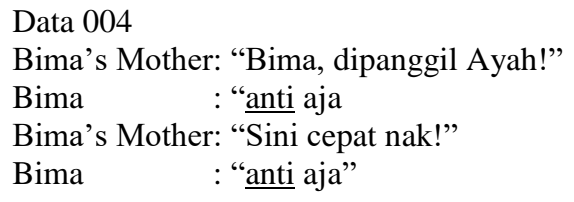

Data 004 shows that language disorders are conveyed by Bima. Bima eliminates the phoneme [n] when saying a word later so that the sound that is heard is anti.

\section{Pragmatic Problems}

Problems related to the integrity of his teachings are often experienced by Bima he often does not focus when asked and gives answers that are not in accordance with what is asked by the interlocutor following the data that shows language disorders pragmatically.

Data 005

Teacher : "Kamu belajar apa tadi malam?"

Bima: (memasang wajah bertanya)

Teacher : "Kamu belajar nggak tadi malam?"

Bima: "Iya"

Teacher : "Belajar apa?"

Bima: "Belajar"

Teacher : "Iya, belajar apa?"

Bima: "Buku"

Teacher : "Belajar buku apa?"

Bima: "eh............IPA"
In data 005, it can be seen that Bima has problems in understanding speech and always thinks long when answering questions given by Bima's teacher. Pragmatic failure can be seen in the example above when the Bima teacher asks whether Bima learned or not last night. Bima put on a face full of question marks and did not answer questions. When the teacher asked Bima, she was learning what Bima answered with the answers from the book.

\section{Data 006}

Bima: "Aku mau makan ayam pahang dan dadang"

Bima's Mother: "Oh, kamu mau makan ayam paha dan dada?"

Bima: "bukan

Bima's Mother: "Tapi tadi kamu minta ayam paha dan dada"

Bima: "Cepat"

In data 006, it can be seen an error in the delivery of utterances as when the mother asked again what Bima wanted but Bima's answer was open. Whereas initially Bima really wanted chicken thighs and breasts but when asked back by his mother Bima answered with the answer no. Seen in the utterance above, Bima does not understand the utterances conveyed by his mother.

Diagnosis

Diagnosis is a term adopted from the medical field. Diagnosis can be interpreted as an effort or process of finding weaknesses or diseases experienced by a person through careful study of data testing of symptoms. At this stage, the researcher tried to give Bima's weaknesses based on teacher observations, interviews with teachers and parents and asked friends from Bima.

Prognosis

Language difficulties will have a direct negative impact on a number of factors if a child has a language disorder, so the child will find it difficult to write, read, communicate, and listen. At the time of writing, children will have difficulty writing because the language they are mastering is not good, as well as when reading, communicating with the speaker and also listening. This can be seen in the learning process that Bima is difficult to understand the interlocutor's communication and difficult to listen to the material well. Not only that, the result of Bima's language disorder is less than the maximum in understanding the information and material conveyed by the teacher orally so that the value achieved by Bima will definitely decrease due to the language disorder he experiences.

In addition, language disorders can make Bima insecure and less sociable with his peers and if the case of language disorders is not immediately given a serious treatment, it will interfere with the development of Bima's intelligence intelligence.

Remedial

At this stage, researchers provide the remedial stage intended in the study is the stage that seeks to make 
healing or improvement in children named Bima who have cases of language disorders. Healing and repair is done by looking at the characteristics of cases experienced by the child. Remedial is expected to provide practical solutions to language disorders experienced by children.

The following explanation relates to remedial that can be given as input to teachers and parents that can be given to Bima as an effort to cure language disorders.

The approach to children is given by the teacher so that he continues to have enthusiasm and have high motivation to improve communication. The teacher must also accompany Bima and be patient in giving attention to him so that he feels comfortable when studying in class and not feel ashamed if asked by the teacher or friend during the learning process.

Parents as the closest person to him must keep the spirit and be sure that he will change and the language used will get better with age and also the therapy that is often given by parents should always encourage children to speak in correct language and exert attentively.

The tutoring approach of peers in communication can be given by the teacher by asking the child's close friend (Bima) to provide input when he has a language disorder or mispronifies certain words. This peer tutor is very appropriate given because as a fellow child of course he is closer and communicates with his peers.

The learning model that can be established as an effort to treat speech disorders faced by Bima is to provide a learning model by reading and speaking with repetitive techniques. Another model is the communication model with the correct speech sentences. The teacher often invites communication to the child named Bima and teaches him to answer according to the questions given by the interlocutor. The teacher also teaches how to answer if there are questions asked by the interlocutor. The technique that can be given is to teach forms and answers to these questions with the right answers.

\section{Evaluation}

The evaluation stage is the final stage carried out by the researcher in case study research. The researcher conducts a final evaluation by considering the results in the five previous stages. This means that at this stage improvements were made based on existing data. Evaluation is a stage to give consideration to cases faced by the subjects in case study research and attempt to provide appropriate therapy for language disorders in children named Bima.

Evaluations found by researchers in language disorders experienced by children named Bima caused by the child's focus because he is a child suffering from ADHD (Attention Deficit Hyperactivity Disorder). He suffered from ADHD disorders because he was born prematurely and Bima's mother took liver medicines during pregnancy. As a result, he is always out of focus and fails to provide feedback when communicating when asked by the teacher during the learning process and say certain words so that there are several phonemes additions or subtractions when speaking. As an effort to motivate therapy from teachers and parents play an important role in efforts to cure language disorders they experience.

\section{CONCLUSIONS}

Language disorders in children are indeed language problems that are often experienced by children at certain ages and needs. In this case study, language disorders that occur in children named Bima are caused by the child's focus when talking because the child has ADHD (Attention Deficit Hyperactivity Disorder). The language impairment became an obstacle for Bima to obtain information and speak verbally. The stages in this case study research are (1) case identification; (2) problem identification; (3) diagnosis; (4) prognosis; (5) remedial and (6) evaluation.

The results of the study show that (1) Bima's language disorder is a language disorder in phonological and pragmatic problems; (2) language disorders that occur in Bima are caused by focussing because the child has an ADHD (Attention Deficit Hyperactivity Disorder) type; (3) speech therapy that can be given by frequently communicating with children, developing speech, and giving peer tutors as well as reading over and over with the right speech.

\section{ACKNOWLEDGMENTS}

Sebagai bentuk rasa syukur kepada Allah SWT, diucapkan terima kasih kepada semua pihak yang telah berkontribusi dalam penelitian ini, sehingga penelitian terlaksana dengan baik.

\section{REFERENCES}

[1] Kholid dan Andika Dutha Bachari. 2009. DasarDasar Psikolinguistik. Bandung: UPI Press

[2] Dita, dkk. 2014. Prevalansi Gangguan Pemusatan Perhatian dan Hiperaktivitas pada Anak dan Siswi Sekolah Dasar Negeri Kecamatan Padan Timur Kota Padang Tahun 2013. Jurnal Kesehatan Andalas, 3(2).

[3] Elizabeth B Hurlock. 1978. Perkembangan Anak Jilid 1. Jakarta: Erlangga.

[4] Iffa Hikmawati dan Erni Hidayati. 2014. Efektivitas Terapi Menulis untuk Menurunkan Hiperaktivitas dan Impulsivitas pada Anak dengan Attention Deficit Hyperactivity Disorder (ADHD). EMPATHY. Jurnal Fakultas Psikologi, 2(1).

[5] Indah, Rohmani Nur. 2017. Gangguan Berbahasa. Malang: UIN-MALIKI Press.

[6] Khoiriyah, dkk. 2016. Model Pengembangan Kecakapan Berbahasa Anak yang Terlambat Bicara (Speech Delay). Jurnal Ilmiah Pendidikan Anak Usia Dini, 1(1).

[7] Pujiati, Tri \& Dien Mardiana Yulanti. 2018. Gangguan Berbahasa pada Anak dengan Ciri ADHD. Jurnal Dialektika, 5(1).

[8] Sunanik dalam Nadwa. 2013. Pelaksanaan Terapi Wicara dan Terapi Sensori Integrasi pada 
Anak Terlambat Bicara. Jurnal Pendidikan Islam, 7(1).

[9] Syamsuddiin \& Damaianti. 2009. Metode Pendidikan Bahasa. Bandung: Remaja Rosdakarya.

[10] Van Tiel, Julia Maria. 2015. Anakku Terlambat Bicara. Jakarta: Prenada Media Group. 